Simposium I Jaringan Perguruan Tinggi untuk Pembangunan Infrastruktur Indonesia, 2016

\title{
Design of Sub-surface Constructed Wetland for Greywater Treatment Using Canna Indica (Case Study: Kelurahan Keputih Surabaya) Athif Husnabilah*, Bieby Voijant Tangahu*
}

*Environmental Engineering Department, Faculty of Civil Engineering and Planning, Institut Teknologi Sepuluh Nopember (ITS), Jl. Arief Rahman Hakim, Surabaya 60111, Indonesia

\begin{abstract}
Untreated greywater is one of sanitation issues that occured in Keputih, Surabaya. In order to manage this sanitation issues, constructed wetland is capable of treating domestic wastewater especially greywater, therefore this method is chosen. Design of constructed wetland is projected for 2019 until 2028 usage. Characteristics of greywater influent is typically: BOD 190,43 mg/l; COD 289,17 mg/l; TSS 206,67 mg/l. Canna indica is selected for this treatment due to maintenance value. Apart from constructed wetland design, standard operating procedure and bill of quantity is also made. From this design, the grewater effluent quality is estimated: BOD $30 \mathrm{mg} / \mathrm{l}$; COD 46,28 mg/l; TSS 26,67 mg/l thus meet the Domestic Wastewater Quality Standard from East Java Governor Regulation No. 7 2013. The cost required to build CW in Kelurahan Keputih Surabaya is Rp 9.156.412.000.
\end{abstract}

Keywords: Canna indica; Constructed Wetland; greywater; phytoremediation; Surabaya City.

\section{Introduction}

In 2012, there are 3.040 and 1531 people suffered from skin disease and diarrhea due to bad sanitation in Keputih, Surabaya respectively. This happened because untreated domestic wastewater is polluting the river [1], therefore wastewater treatment that suitable with the region is needed. Keputih has ex-landfill area of 40,5 Ha which has been closed in 2001, and allocated as green area in city development plan[2], thus ex-landfill area in Keputih is selected.

Method of treatment in this design is constructed wetland using Canna indica as its main vegetation. Constructed Wetland is controlled treatment system design and built around natural process (vegetation). This vegetation includes sandy soils and microorganism for wastewater treatment. Constructed wetland cost less than conventional wastewater treatment in term of both investation and maintenance cost [3]. Constructed wetland also has 97\% removal of TSS [4], odorless [5] and has high value of aesthetics [6]. There are two types of Constructed Wetland, surface flow and sub-surface flow. Surface flow Constructed Wetland could increase mosquito population around constructed Wetland area, thus makes sub-surface constructed wetland is more suitable in Indonesia [7]. Sub-surface Constructed Wetland utilize natural symbiosis between vegetation and microorganism in the area [8].

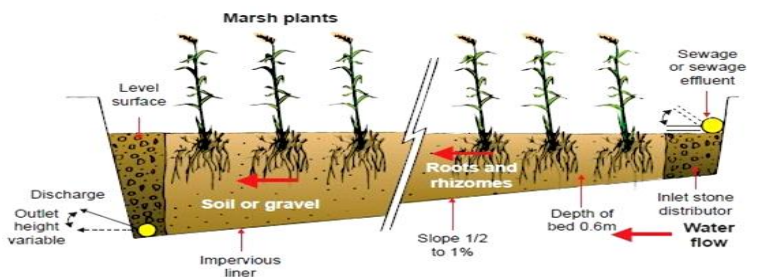

Fig 1. Sub-surface Constructed Wetland [9]

\section{Keputih Overview}

Keputih is part of Surabaya City that has 40 RT (Rukun Tetangga) and 9 RW (Rukun Warga). Keputih is considered lowland area with altitude of 5 meters above sea-level. It has area of $14440 \mathrm{Ha}$. The average temperature in Keputih is between $28^{\circ}-$ $36^{\circ} \mathrm{C}[10]$. Keputih is surrounded with:

$\begin{array}{ll}\text { - Kelurahan Kejawan Tambak } & \text { : North side } \\ \text { - Madura Strait } & \text { : East side } \\ \text { - Kelurahan Semolowaru and Medokan Semampir } & \text { : South side } \\ \text { - Kelurahan Klampis Ngasem } & \text { : West side }\end{array}$

\section{Design Methods}

Methods used in this design is unit dimensions calculation, BoQ calculation, and standard operating procedure of treatment unit. Unit dimensions calculation is based on greywater quality and quantity in Keputih. Greywater quantity (flow) calculation

* Corresponding author. Tel.: +62 85736024151

E-mail address: athif120694@gmail.com 
depends on clean water usage per person while greywater quality is based on laboratory analysis. Methods of analysis to determine greywater quality [11] is shown in Table 1.

Table 1. Methods used for Greywater Quality Analysis

\begin{tabular}{cc} 
Parameters & Methods \\
\hline BOD & Winkler Method \\
\hline COD & Closed Reflux Titrimetric Method \\
\hline TSS & Gravimetric Method \\
\hline pH & pH Meter Method
\end{tabular}

Effluent standard used in this design is the Domestic Wastewater Quality Standard from East Java Governor Regulation No. 7 year 2013. BOQ calculation is based on Harga Satuan Pokok Pekerja (HSPK) Surabaya City 2015.

\section{Design Results}

\subsection{Keputih Population Projection}

Design periods of this Constructed Wetland is 2019-2028, while 2016-2018 is the initial years of this Constructed Wetland. There are 3 methods to calculate population projection, arithmetic, geometric, and least square. The selected method is one with correlation factor closest to 1 and lowest standard deviation value [12]. Data used for population projection is population data from 2011-2015. Based on the calculation, population of Keputih in 2028 is projected about 26.982 people.

\subsection{Greywater Quality and Quantity Determination}

Greywater quantity is determined from Keputih citizens water bill (per house) about 164,5 L/person.day while $75 \%$ of those fresh water turned out to be greywater [13]. Calculation of greywater quantity is as follows:

$$
\begin{aligned}
& \mathrm{Q}_{\text {ave }} \text { fresh water }=\text { fresh water usage/person.day } \times \text { population } \\
& \mathrm{Q}_{\text {ave }} \text { greywater }=75 \% \times \text { Qave fresh water }
\end{aligned}
$$

Based on (1) and (2) equations, greywater quantity in Keputih year 2028 is $3.329,29 \mathrm{~m}^{3} /$ day. Greywater quality obtained from laboratory analysis is shown in Table 2 .

Table 2.Greywater Influent Quality

\begin{tabular}{cc} 
Parameters & Value \\
\hline BOD & $190,4 \mathrm{mg} / \mathrm{L}$ \\
\hline COD & $289,6 \mathrm{mg} / \mathrm{L}$ \\
\hline TSS & $206,7 \mathrm{mg} / \mathrm{L}$ \\
\hline $\mathrm{pH}$ & 7,8 \\
\hline Temperature & $28,4^{\circ} \mathrm{C}$
\end{tabular}

\subsection{Unit Dimensions Calculation}

Constructed Wetland in this design is also equipped with 1 unit of collecting basin and 3 units of indicator basin. Collecting basin function is to collect greywater before entering Constructed Wetland while indicator basin serves to test greywater effluent with biological indicator (fish) before entering river. Collecting basin dimension is designed $4 \times 4 \times 3,3 \mathrm{~m}$ (length $\mathrm{x}$ width $\mathrm{x}$ height) while indicator basin dimensions is designed $12 \times 6$ × 2,3 m (length x width x height). Design criteria for Constructed Wetland is as follows:

- TSS Removal: $60-75 \%$

- $\quad$ BOD Removal (by media) : 75\% - 98\%

- BOD Removal (by vegetation): $4,4 \%$

- HLR: $0,2-1 \mathrm{~m}^{3} / \mathrm{m}^{2}$.day

- Length : width ratio: 4:1 - 10:1

The equation used for this design is as follows [17]:

$\frac{c_{e}}{c_{o}}=e^{-K t .-t d}$

$K t=K_{20}(1,1)^{t-20}$

$\mathrm{t}^{\prime}=-\ln \frac{\left(\frac{(e)}{c o}\right)}{K_{T}}$

$A s=d \cdot W=\frac{Q}{K t . S}$

$L=\frac{t d \cdot Q}{W \cdot d \cdot \alpha}$ 
Where:

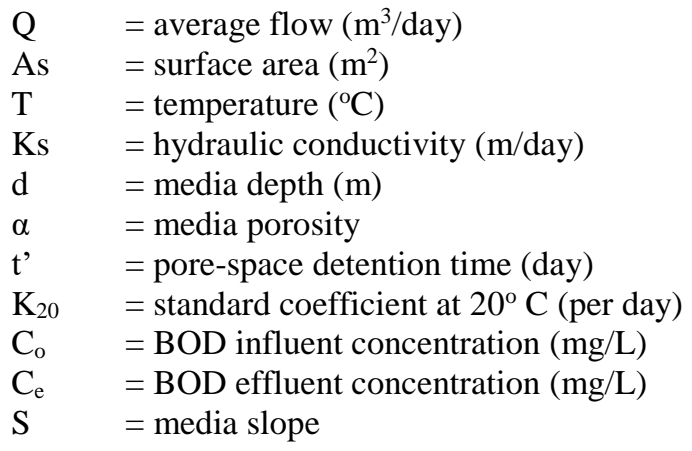

There are 6 constructed wetland designed with 0,6 media depth $\mathrm{m}$ and 0,01 slope. Media depth is adjusted according to Canna indica root that can grow up to $0,6 \mathrm{~m}$. Media used in this constructed wetland is medium gravel whose Ks value is 5000 $\mathrm{m}^{3} / \mathrm{m}^{2}$.day, alpha $=0,4$ and $\mathrm{k}_{20}=1,104$ [5]. Effluent must comply with regulation, BOD $<30 \mathrm{mg} / \mathrm{l}, \mathrm{COD}<50 \mathrm{mg} / \mathrm{l}, \mathrm{TSS}<50$ $\mathrm{mg} / \mathrm{l}$ and $\mathrm{pH}$ 6-9. Degradation process in Constructed Wetland not only occurs in media, but also in vegetation and rhizobacteria. Rhizobacteria lives in collony and together with rhizome. It uses greywater as food source. Constructed wetland with vegetation (planted) has higher value of BOD removal (higher 4,4\%) than the unplanted one [15]. The function of plant in Constructed Wetland provides hydraulic line in media and to keep greywater conductivity stable [18].

Based on (3) - (8) equations, dimension of constructed wetland is $125 \mathrm{~m} \mathrm{x} 19 \mathrm{~m}$ x $1 \mathrm{~m}$ (length x width x depth). Hydraulic loading rate (HLR) of this Constructed Wetland is $0,23 \mathrm{~m}^{3} / \mathrm{m}^{2} /$ day. This design is expected to remove $84,25 \%$ of influent BOD and $85 \%$ of influent COD[19]. Meanwhile, the removal of TSS is calculated using equation (9) below:

From the (9) equation, the TSS removed is $27,17 \mathrm{mg} / \mathrm{L}$. So, the Constructed wetland's removal efficiency of TSS is $87,10 \%$.

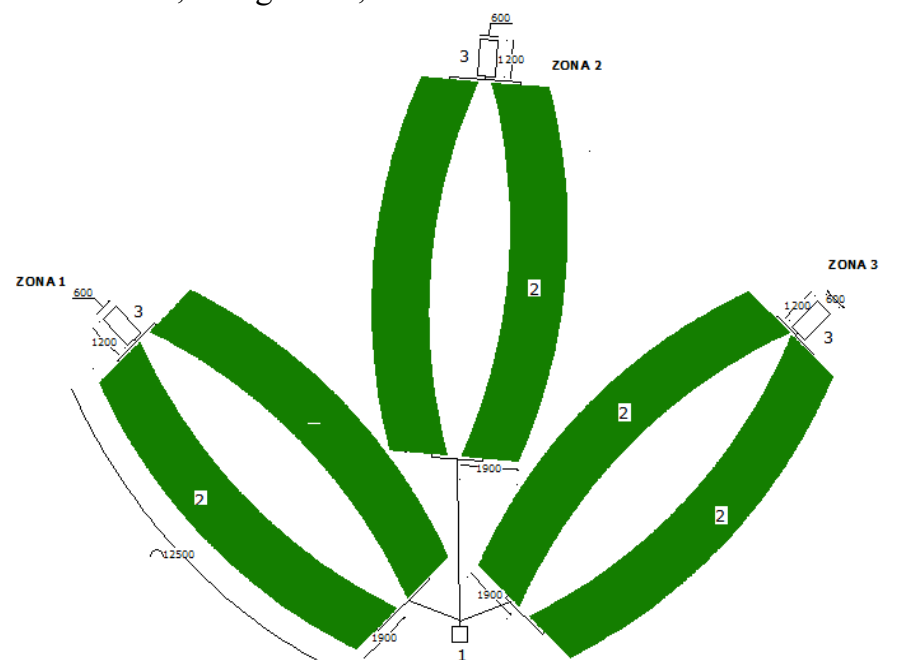

Fig 2. Constructed Wetland Layout ( $1=$ collective basin, $2=$ Constructed Wetland, $3=$ indicator basin $)$

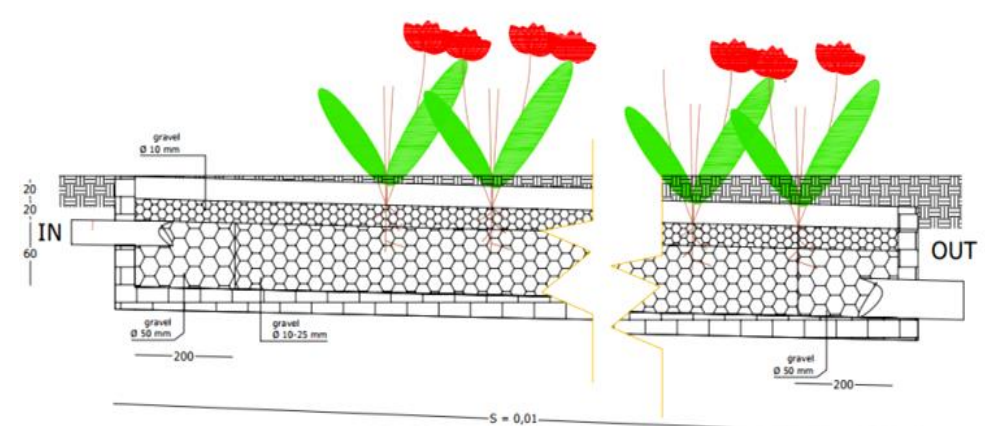

Fig 3. Constructed Wetland Cross-Section View

Influent $\left(\mathrm{Q}_{\text {in }}\right)$ is not the same with Effluent $\left(\mathrm{Q}_{\text {out }}\right)$. Effluent is affected by evapotranspiration rate, precipitation, and 
infiltration. The effluent is calculated using this formula.

$\mathrm{Q}_{\mathrm{ef}}=\mathrm{Q}_{\text {in }}-\mathrm{Q}_{\mathrm{ET}}+\mathrm{Q}_{\mathrm{P}}+\mathrm{Q}_{\mathrm{I}}$
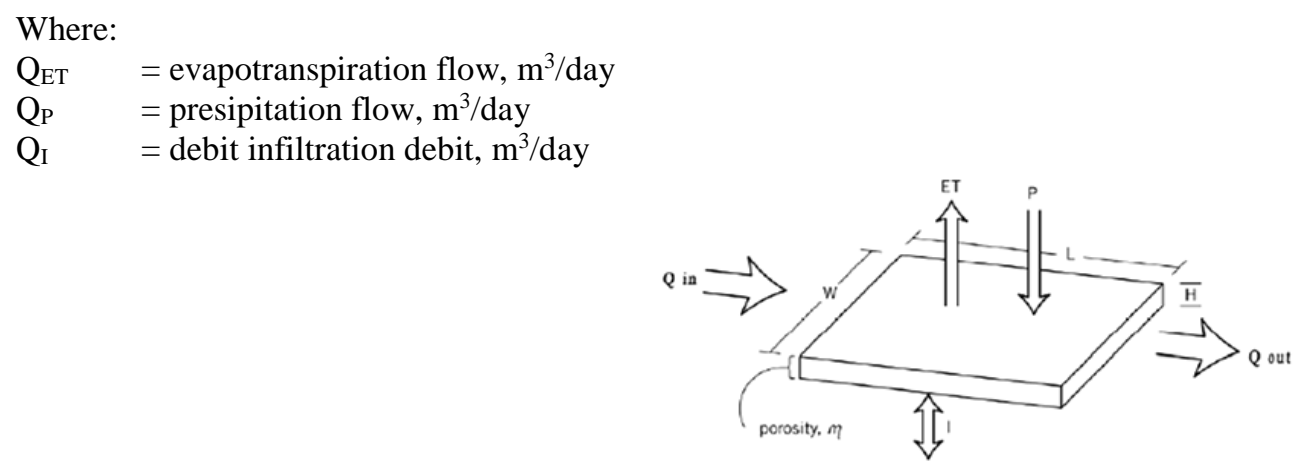

Fig 4. Constructed Wetland Water Budget

The evapotranspiration rate of Constructed Wetland planted with Canna indica is 28,55 mm/day [20]. Meanwhile, the precipitation rate in Surabaya is $18,8 \mathrm{~mm} /$ day [8]. There is no infiltration rate $\left(\mathrm{Q}_{\mathrm{I}}=\right.$ zero) because the Constructed Wetland lined with geomembrane. Based on the equation above, the effluent of Constructed Wetland is $3.190,36 \mathrm{~m}^{3} / \mathrm{day}$.

\section{BoQ (Bill of Quantity) Result Calculation}

Along with 6 constructed wetlands, 1 unit of collecting basin and 3 units of indicator basin is also designed. Total expenses for all of treatment units is 9.156.412.000 rupiah.

\section{Conclusion}

Treatment units that is designed, including: Collecting basin ( 1 unit), dimension: 4 x 4 x 3,3 m; Constructed Wetland (6 units), dimension $19 \times 25 \times 1 \mathrm{~m}$, Indicator basin ( 3 units), dimension 6 × $12 \times 2,3 \mathrm{~m}$. BOD, COD, and TSS removal efficiency is $84,25 \%, 85 \%$, and $87,10 \%$ respectively. Effluent from Constructed Wetland is comply with greywater effluent standard. Total expenses for all of treatment units is 9.156.412.000 rupiah. This constructed wetland unit is designed to serve $100 \%$ of Keputih population in 2028 which is 29.982 people.

\section{References}

[1] R. S. Pratiwi, "Perencanaan Anaerobic Baffled Reactor (ABR) di Kelurahan Keputih Surabaya," Surabaya, 2015.

[2] J. Silas, H. R. S., W. Setyawan, H. IDAA Warmadewanthi, and Susetyo Firmaningtyas, "Revitalisasi eks TPA Keputih menjadi taman kota untuk mendukung Surabaya menuju eco-city," in Simposium Nasional RAPI XIII, 2014.

[3] M. M. Villar, E. . Perez, F. T. Dominguez, J. M. H. Ruiz, R. S. Morales, and L.E. Arteaga, "Vertical subsurface wetlands for wastewater purification," in Proccedia Engineering, 2012, pp. 1960-1968.

[4] L. Puspita, E. Ratnawati, I. N. N. Suryadiputra, and A. A. Meutia, Lahan basah buatan di Indonesia. Wetlands Indonesia, 2005.

[5] Environmental Protection Energy (EPA), "Subsurface flow cnstructed wetlands for wastewater treatment," 2003.

[6] W. Gunawan and Suswati, "Pengolahan Limbah Domestik Dengan Teknologi Taman Tanaman Air (Constructed Wetlands)," Indones. Green Technol., vol. 2, 2013.

[7] Supradata, "Pengolahan limbah domestik menggunakan tanaman hias Cyperus alternifolius L. dalam sistem lahan basah buatan aliran bawah permukaan (SSF-wetlands)," Universitas Diponegoro, 2005.

[8] N. K. Sari, H. Harsa, and R. Boedisantoso, "Penentuan korelasi curah hujan, ketinggian lapisan inversi dan hubungannya dengan kualitas udara ambien Kota Surabaya," J. Tek. ITS, vol. 4, no. 1, 2015.

[9] C. H. Sim, The use of constructed wetlands for wastewater treatment. Malaysia: Wetlands International, 2003.

[10] Kelurahan Keputih Kota Surabaya, "Monografi Kelurahan Keputih Bulan April-Juni 2015,” Surabaya, 2015.

[11] American Public Health Association, merican Water Works Association (AWWA), and Water Environment Federation $(W E F)$, "Standard methods for the examination of water and wastewater 20th edition. Baltimore: United Book Press, Inc, 1999.

[12] N. Y. Kisman, "Evaluasi dan perencanaan instalasi pengolahan air minum Kota Kendari Sulawesi Tenggara," Bandung, 2007.

[13] P. Hlavinek, O. Bonacci, J. Marsalek, and I. Mahrikova, Dangerous pollutants (xenobiotics) in urban water cycle. Springer, 2007. 
[14] J. Vymazal, "Constructed wetlands for wastewater treatment in the Czech Republic," Water Sci. Technol., vol. 44, pp. 369-374, 2001.

[15] M. M. Diaz, Otoniel Carranza Luciana Schultze-Nobre, J. Nivalac, P. Kuschk, and Heinz Koeser, "Removal Of selected organic micropollutants in planted and unplanted pilot-scale horizontal flow constructed wetlands under conditions of high organic load," Ecol. Eng., vol. 71, pp. 234-245, 2014.

[16] J. B. Ellis, R. B. E. Shutes, and D. M. Revitt, "Guidance manual for constructed wetlands," 2003.

[17] Metcalf and Eddy, Wastewater Engineering : treatment and reuse, fourth edition, international edition. New York: Mc Graw Hill, 2003.

[18] D. . Mara, "Constructed wetlands are not a viable alternative or addition to waste stabilization ponds," in IWA Specialist Conference on Waste Stabilization Ponds, 2006.

[19] C. S. Akratos and Vassilios A. Tsihrintzis, "Effect of temperature, HRT, vegetation and porous media on removal efficiency of pilot-scale horizontal sibsurface flow constructed wetlands," Ecol. Eng., vol. 29, pp. 173-191, 2006.

[20] Konnerup, Dennis, T. Koottatep, and Hans Brix, "Treatment of domestic wastewater in tropical, subsurface flow constructed wetlands planted with canna and heliconia," Ecol. Eng., vol. 35, pp. 248-257, 2008.

\section{Use the "Insert Citation" button to add citations to this document.}

[21] Wallace, Scott D. and Robert L. Knight, "Small scale constructed wetland treatment systems : feasibility, design criteria, and O\&M requirements", The Water Environment Research Fondation: United kingdom (2006). 